ljtihad: Jurnal Wacana Hukum Islam dan Kemanusiaan

Vol. 18, No. 2 (2018), pp. 211-226, doi : 10.18326/ijtihad.v18i2.211-226

\title{
Implementasi jaminan produk pangan halal di Jambi
}

\author{
Ulya Fuhaidah Ramlah \\ Fakultas Syariah UIN Sulthan Thaha Saifuddin Jambi \\ E-mail:ulyafubaidah@uinjambi.ac.id \\ doi : 10.18326/ijtihad.v18i2.211-226
}

This research aims to explore how the role of the government in the circulation of halal food in Kuala Tungkal City. Kuala Tungkal is one of the entry points for the circulation of imported goods located in Singapore, Johor, Riau (SIJORI). In general, imported food in circulation already has a BPPOM register number, but no halal label. Even though the law on halal products has been passed since 2014 by the government. The approach used in this research is the fiqh approach. The method of data collection conducts by observation, in-depth interviews, and documentation. The purposive sampling technique was chosen to determine the criteria for the informants to be interviewed, namely the Chair of the MUI and the head of the BPPOM of Jambi Province. The results of the study indicate that the regulation of guaranteed halal food has been regulated for a long time in Indonesia, but it has not been applied properly. The obstacles and challenges of implementing halal food related to three factors, namely the limited authority of stakeholders in the region, lack of budget, human resources, and inadequate infrastructure.

Riset ini bertujuan untuk mengeksplorasi bagaimana peran pemerintah terhadap peredaran produk pangan halal terutam yang beredara di Kota Kuala Tungkal dan Kota Jambi. Kota Kuala Tungkal adalah salah satu pintu masuknya peredaran barang impor yang terletak di wilayah Singapura, Johor, Riau (SIJORI). Makanan impor yang beredar pada umumnya sudah memiliki nomor register BPPOM, namun tidak memiliki label halal. Padahal undang-undang jaminanan produk halal sudah disahkan sejak 2014 oleh pemerintah. Pendekatan yang dipakai dalam riset ini adalah pendekatan fiqh. Metode pengumpulan data dilakukan dengan cara observasi, wawancara mendalam, dan dokumentasi. Teknik purposive sampling dipilih untuk menentukan kriteria para informan yang akan diwawancarai yakni Ketua MUI dan kepala BPPOM Propinsi Jambi. Adapun hasil penelitian menunjukkan bahwa regulasi jaminan pangan halal sudah diatur sejak lama di Indonesia, namun belum dapat diaplikasikan dengan baik. Hambatan dan tantangan implementasi jaminan produk halal muncul di lapangan terkait dengan tiga faktor yakni keterbatasan kewenangan stake holder di daerah, kurangnya anggaran, sumber daya manusia, dan infrastruktur yang kurang memadai.

Keywords: halal; food product; Kuala Tungkal 
ljtihad: Jurnal Wacana Hukum Islam dan Kemanusiaan, Volume 18, No. 2, Desember 2018: 211-226

\section{Pendahuluan}

Kota Kuala Tungkal berada di pesisir laut dan berbatasan langsung dengan Provinsi Riau maupun negara tetangga yaitu Singapura-Johor-Riau atau yang biasa dikenal dengan wilayah SIJORI (Hutchinson and Chong, 2016). Kondisi yang demikian menjadikan wilayah ini berada pada posisi yang rawan akan peredaran barang-barang tak berizin di tengah kondisi perekonomian global(kajanglakonews.com; lintastungkal.com). Selain maraknya barang ilegal, peredaran barang yang menimbulkan kekhawatiran utamanya adalah produk makanan dan minuman tanpa label halal baik berasal dari negeri jiran maupun produk dalam negeri.

Sebagaimana diketahui, kehalalan makanan dalam Islam adalah faktor terpenting dalam memilih makanan. Hal ini sesuai dengan firman Allah SWT di dalam al-Quran Surah AlBaqarah ayat 168-169:

"Hai sekalian manusia, makanlah yang halal lagi baik dari apa yang terdapat di bumi, dan janganlah kalian mengikuti langkah-langkah setan; karena sesunggubny setan itu adalah musub yang nyata bagi kalian. Sesunggubnya setan itu banya menyurub kalian berbuat jabat dan keji, dan mengatakan terhadap Allah apa yang tidak kalian ketahui".

Dari ayat di atas dapat diketahui bahwa memilih makanan yang halal tidak hanya kewajiban umat Islam, tetapi berlaku universal bagi manusia tanpa memandang agama, suku, dan ras mereka. Jika berlaku hanya bagi umat Islam, maka kalimat yang dipakai Al-Quran adalah "wahai orang-orang yang beriman” (Man\&Yahya, 2014:X). Oleh karena itu, Islam menganjurkan agar makanan dan minuman yang akan dikonsumsi harus memenuhi unsur halal.

Kehalalan makanan harus memenuhi empat unsur mulai dari cara memperolehnya, yakni melalui rizki yang halal. Kedua, halal zat atau bahan dasarnya. Sebagaimana firman Allah SWT bahwa segala yang ada di alam ini halal untuk seluruh manusia kecuali hewan dan tumbuhan yang diharamkan dalam Al-Quran yakni bangkai, darah, daging babi dan binatang yang tercekik, dipukul, dan disembelih dengan tidak menyebut Nama Allah. Adapun tanaman yang diharamkan adalah khamr. Ketiga, halal dalam proses pengolahan. Dalam artian tidak tercampur sedikitpun dengan barang haram. Keempat, halal dalam proses pengemasan (Faidah, 2017: 452).

Mengkaji tentang kehalalan produk makanan dan minuman di Indonesia sudah dilakukan oleh beberapa periset. Apabila disintesiskan, maka risettersebut terbagi menjadi beberapa 
wacana yakni jaminan produk halal di Indonesia (Lim, 2018: 99-107), pelaksanaan sertifikasi halal bagi industri farmasi (Salim, 2018), perilaku pembelian kosmetik berlabel halal oleh konsumen Indonesia (Endah, 2018: 25-39), Sertifikasi dan Labelisasi Produk Halal Perspektif Maslahat (Ilyas, 2018: 357-376), dan pelaksanaan Undang-Undang Nomor 33 Tahun 2014 Tentang Jaminan Produk Halal Terhadap Pendaftaran Sertifikat Halal pada produk maknan (Hosana\&Nugroho, 2018). Dari riset yang telah disebutkan, belum terdapat kajian tentang jaminan produk halal di tingkat lokal yakni wilayah Kuala Tungkal di mana wilayah ini merupakan pintu masuknya peredaran barang-barang dari luar negeri. Dengan demikian gap antara riset ini dengan riset terdahulu terkait dengan wilayah penerapan jaminan produk pangan halal. Untuk menguraikan kajian ini, maka penulis ingin menjawab pertanyaan riset tentang bagaimana implementasi jaminan halal di Indonesia dan bagaimana hambatan yang ditemui oleh stake holder di Kuala Tungkal terkait dengan realisasi jaminan halal di tingkat lokal. Pertanyaan ini muncul seiring dengan masih ditemukannya produk pangan yang tidak memiliki label halal pada kemasannya dan beredar di wilayah Kuala Tungkal Jambi sejak disahkannya UU JPH.

\section{Landasan teori}

Dalam bahasa Arab makanan berasal dari bentuk mufrad طعم dan jamaknya الاطعمد yang mempunyai arti makanan. Dalam ensiklopedi hukum Islam makanan adalah segala sesuatu yang boleh dimakan oleh manusia atau sesuatu yang dapat menghilangkan rasa lapar. Sedangkan halal berasal dari bentuk derifative kata حال yang berarti "diizinkan" atau “dihalalkan”. Pemakaian kosakata ini lebih sering digunakan untuk merujuk kepada makanan yang diizinkan untuk dikonsumsi menurut Islam. Halal merupakan sesuatu yang mubah atau diperkenankan, yang terlepas dari ikatan larangan dan diizinkan oleh Pembuat Syari'at.

Dalam kajian fiqh maupun ushul fiqh, halal merupakan bagian dari hukum taklifi.Hukum ini adalah hukum yang menuntut subyek hukum (mukallaf) untuk melakukan perbuatan dalam berbagai bentuk baik perbuatan yang diperintah untuk melakukannya, atau perbuatan terlarang yang dituntut untuk meninggalkannya, maupun perbuatan yang diberikan pilihan di antara keduanya yakni antara melakukan atau meninggalkannya (Zulham, 2018: 1) . 
ljtihad: Jurnal Wacana Hukum Islam dan Kemanusiaan, Volume 18, No. 2, Desember 2018: 211-226

Menurut jumhur ulama Islam, hukum taklifi dibagi menjadi lima kategori yakni (1) wajib (obligatory), (2) mandub atau sunnah (recommended), (3) mubah (permissible), (4) makruh (reprehensible), (5) haram (probibited). Sementara mazhab Hanafi membaginya menjadi tujuh bagian yakni (1) fardhu (obligatory), (2) wajib (obligatory), (3) mandub atau sunnah (recommended), (4) mubah (permissible), (5) makruh al-tabrim (abomination), (6) makruh al-tanzih (disapprovah), dan (7) haram (probibited).

Halal berarti membebaskan, melepaskan, memecahkan dan membolehkan.Dalam kaitan dengan hukum syara", halal memiliki dua pengertian yaitu pertama "Segala sesuatu yang tidak dikenakan dosa apabila menggunakannya" dan kedua "Segala sesuatu yang telah diperbolehkan syara' baik untuk mengerjakannya atau memanfaatkannya" (Zulham, 2018:2). Pengertian pertama menunjukkan bahwa kata halal menyangkut kebolehan (mubah) menggunakan benda-benda atau apa saja seperti kosmetika, minyak wangi dan lain-lain. Pengertian kedua berkaitan dengan kebolehan memanfaatkan dan mengerjakan sesuatu yang kesemuanya ditentukan berdasarkan nash seperti makan, minum, termasuk mengkonsumsi obat- obatan.

Al-Asqar sebagaimana dikutip oleh Zulham, berpandangan bahwa dalil-dalil yang menyatakan mubah adalah: Pertama, lafaz yang menyatakan kehalalan, perizinan, tidak bersalah, tidak berdosa, dan lainnya mengacu kepada makna mubah dan halal. Kedua, perbuatan Rasulullah yang menunjukkan tidak ada perintah untuk melakukannya dan meninggalkannya. Ketiga, perkataan Rasulallah yang disaksikan atau disampaikan kepada para sahabat dan tidak mengandung unsur wajib maupun sunnah. Keempat, setiap perbuatan yang didiamkan syariatdengan tidak menuntut untuk meninggalkannyayang disebut dengan al ibahah al aqliyah dan perbuatan yang dibolehkan dalam syariat yang disebut al ibahah al syar'iyyah

Selanjutnya Al-Asyqar juga menjelaskan kaidah-kaidah tentang mubah sebagai berikut: Pertama, kaidah mubah termasuk ke dalam hukum taklifi. Kedua, kaidah mubah dapat menjadi wajib dari sisi asalnya jika dilihat dari sisi individu. Mengkonsumsi makanan halal hukumnya boleh, dimana manusia bebas memilih makanan apapun. Oleh karenanya makan hukumnya wajib karena meninggalkan makan berakibat pada kematian dan kepunahan manusia. Kaidah ini tentu sesuai dengan tujuan maqasid syariah dimana manusia wajib menjaga dirinya. Ketiga, kaidah perubahan mubah menjadi sunnah, wajib, haram atau lainnya 
karena perbedaan niat dan kondisi. Sebagai contoh misalnya mengkonsumsi makanan karena berniat untuk melakukan maksiat. Dalam kondisi seperti ini, maka sesuatu yang mubah berubah menjadi haram.

Dalam al-Qur'an surat al-Maidah ayat 88 dijelaskan bahwa manusia diperintahkan (diwajibkan) untuk mengkonsumsi makanan yang halal dan toyib (baik). Kewajiban mengkonsumsi makanan halal ini bertujuan menciptakan kemaslahatan, kebaikan dan kesejahteraan (falah) untuk manusia itu sendiri.Dari tujuan ini dapat ditemukan nilai-nilai yang terkandung di dalamnya sesuai dengan maqashid syariah.

Maqasid Syariah terdiri dari dua kata yakni maqasid dan syariah. Kata maqasid merupakan bentuk jamak dari kata maqsud yang memiliki sekurangnya tiga makna sebagaimana yang tercantum dalam Lisan Al-Arab di antaranya: Bercita-cita (al-i'tizam), pegangan (al-'itimad), bersengaja (al-amm) meminta sesuatu dan mendatangkannya. Makna-makna ini terdapat dalam hadis Nabi SAW

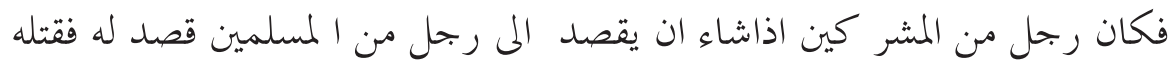

Jalan yang benar atau lurus seperti disebutkan dalam firman Allah

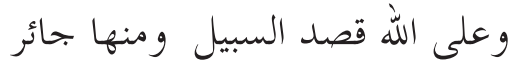

Sedangkan kata syariah memiliki arti hukum-hukum Allah yang ditetapkan untuk manusia agar dipedomani untuk mencapai kebahagiaan hidup di dunia dan di akhirat. Maka dengan demikian, maqasid syariah adalah tujuan-tujuan yang hendak dicapai dari suatu penetapan hukum (Shidiq, 2018: 118).

Berdasarkan kajian historis, imam al-Juwaini dapat dikatakan sebagai ahli ushul fiqh pemrakarsa pentingnya memahami maqasid syariah dalam menetapkan hukum Islam. Ia secara tegas mengatakan bahwa seseorang tidak dapat dikatakan mampu menetapkan hukum dalam Islam sebelum ia memahami benar-benar tujuan Allah mengeluarkan perintah-perintah dan larangan-larangannya. Al Juwaini membagi tujuan tasyri' menjadi tiga macam dharuriyat, bajiyat, dan mukramat (Shidiq, 2018: 122).

Dharuriyat adalah maslahat yang bersifat primer dimana kehidupan manusia sangat tergantung padanya baik aspek duniawi maupun ukhrawi. Jika aspek ini tidak ada, maka kehidupan dunia ini dapat hancur. Hajiyat yaitu maslahat yang bersifat sekunder, yang 
ljtihad: Jurnal Wacana Hukum Islam dan Kemanusiaan, Volume 18, No. 2, Desember 2018: 211-226

diperlukan oleh manusia untuk memudahkan dalam kehidupan dan menghilangkan kesempitan. Tabsiniyat yaitu maslahat yang merupakan tuntutan moral dan itu diperuntukkan bagi kebaikan dan kemuliaan. Jika tidak ada, tidak sampai merusak dan menyulitkan kehidupan manusia.

Selanjutnya, al-Syatibi dianggap sebagai ulama yang membahas secara khusus, sistematis dan jelas maqasid syariah dalam kitabnya yang berjudul al-Muwafaqat. Dalam kitabnya, ia menegaskan bahwa tujuan Allah menetapkan hukum-hukumnya adalah untuk terwujudnya kemaslahatan.

Maqashid Syariah dalam makanan halal ini dideskripsikan dalam kelima pokok addharuriyatul khamsah sesuai peringkatnya masing-masing dengan berpegang pada terjaganya lima pokok kemaslahatan, yakni agama, jiwa, akal, keturunan, dan harta. Makanan halal erat kaitannya dengan Hifdu al-din (menjaga/memelihara agama) karena jelas telah diwajibkan di dalam Al-Quran.Siapapun yang melaksanakan kewajiban tersebut, artinya telah mengamalkan doktrin agama dalam kehidupannya.

Sementara maqashid syariah kedua, menjaga jiwaterkait dengan kehiegenisan dan kandungan makanan halal dan tayyib.Pada umumnya jenis makanan ini adalah makanan yang tidak membahayakan jiwa sebagaimana khamr yang telah dilarang karena terbukti secara ilmiah merusak otak dan organ tubuh lainnya. Oleh karena itu, makanan halal juga sesuai dengan maqasid syariah yang selanjutnya yakni memelihara akal, keturunan, dan harta.

Sebagaimana penemuan ahli ilmu gizi, bahwa konsep makanan halal dan tayyib adalah makanan yang memiliki kriteria: sehat, dalam artian memiliki zat gizi yang cukup dan seimbang; proporsional,yakni memperhatikan kebutuhan nutrisi sesuai usia; dan aman yaitu makanan yang tidak membahyakan kesehatan dan menjadi penyebab berbagai macam penyakit yang akan berujung kepada kematian, walaupun sudah berobat dan menghabiskan biaya yang tidak sedikit.

Menurut para ahli, di antara pengaruh makanan terhadap tubuh memiliki keuntunganjasmani maupun rohani sebagai berikut:Mempengaruhi tubuh dan kecerdasan akal, Mempengaruhi sifat dan perilaku, Mempengaruhi perkembangan anak-keturunan, Mempengaruhi diterima atau ditolaknya amal ibadah dan doa, Mempengaruhi keselamatan di akhirat, Mengkonsumsi yang halal sebagai ibadah yang wajib (Asyari, 2018:50-53). 
Muhammad Akbar Khan berpendapat bahwa setiap negara wajib berperan untuk melindungi semua hak dan kebebasan individu yang fundamental yang diderivasikan dari al daruriyat al khamsah yakni: pertama, negara harus menjamin bahwa setiap muslim melaksanakan agamanya. Kedua, negara harus menjamin keamanan dan kesejahteraan semua rakyatnya. Ketiga, negara harus memfasilitasi kondisi untuk pertumbuhan pikiran yang sehat seperti memberikan kebebasan berekspresi dan pendidikan universal. Keempat, negara harus menciptakan kondisi untuk berkembangnya sistem keluarga yang sehat. Kelima, negara harus menjamin kesejahteraan ekonomi rakyat secara keseluruhan (Zulham, 2018: 12)

\section{Regulasi jaminan kehalalan produk pangan di Indonesia}

Pangan adalah istilah yang mencakup aspek luas di dalamnya.Laura J. Harper merumuskan bahwa pangan adalah bahan yang dimakan guna memenuhi kebutuhan tubuh untuk tumbuh, bekerja, dan perbaikan jaringan. Dalam definisi undang-undang, istilah pangan mengalami pergeseran. Undang-Undang Pangan Tahun 1996 pada pasal 1 angka 1 merumuskan bahwa pangan adalah segala sesuatu yang berasal dari sumber hayati dan air yang diolah maupun tidak diolah yang diperuntukkan sebagai makanan atau minuman bagi konsumsi manusia, termasuk bahan tambahan pangan, bahan baku pangan, dan bahan lain yang digunakan dalam proses penyimpanan, pengolahan, dan atau pembuatan makanan atau minuman (Konoras, 2017: 44).

Isu jaminan produk halal mulai digagas oleh pemerintah sejak berlakunya Undang-undang Nomor 33 Tahun 2014 tentang Jaminan Produk Halal (selanjutnya disingkat UU JPH) yang disahkan dan diundangkan sejak 17 Oktober 2014. Pemerintah menerapkan peraturan baru bahwa seluruh produk yang dijual di Indonesia harus mencantumkan label halal.Peraturan ini kemudian menimbulkan kontroversi di masyarakat. Satu sisi peraturan ini akan menjamin beredarnya produk halal bagi konsumen muslim, tetapi di sisi lain pengurusan sertifikasi halal dianggap memberatkan pelaku bisnis.

Kehalalan makanan bagi umat Islam merupakan aspek utama dalam memilih produk pangan. Sebagaimana diketahui, bahwa teknologi pangan berkembang begitu pesat.Terdapat sejumlah senyawa yang dicampurkan pada makanan dan diproduksi dalam skala besar oleh sebuah perusahaan makanan tanpa sertifikasi halal. Oleh karena itu, pada bab ini akan 
ljtihad: Jurnal Wacana Hukum Islam dan Kemanusiaan, Volume 18, No. 2, Desember 2018: 211-226

membahas tentang bagaimana regulasi dan perundang-undangan yang mengatur tentang jaminan produk pangan halal di Indonesia sebelum disahkannya Undang-Undang Jaminan Produk Halal

Pertama, Undang-Undang Nomor 8 Tabun 1999 tentang Perlindungan Konsumen. Undang-Undang Perlindungan Konsumen (UU Konsumen) memiliki azas manfaat, keadilan, keseimbangan, keamanan dan keselamatan konsumen, dan kepastian hukum. Hak-hak atas konsumen terdapat pada pasal 4 yakni: (1). Hak atas keamanan, kenyamanan, dan keselamatan dalam mengkonsumsi barang dan jasa;(2). Hak untuk memilih barang dan jasa dan mendapatkan barang/jasa tersebut sesuai dengan nilai tukardan kondisi yang dijanjikan;(3). Hak atas informsi yang jelas, benar, dan jujur mengenai kondisi dan jaminan barang/jasa;(4 ). Hak untuk didengar pendapnya atas barang atau jasa yang digunakan;(5). Hak untuk mendapatkan advokasi, perlindungan, dan upaya penyelesaian sengketa perlindungan konsumen secara patut;(6). Hak untuk mendapat pembinaan dan pendidikan konsumen;(7). Hak untuk diperlakukan atau dilayani secara benar dan jujur secara tidak diskriminatif; (8). Hak untuk mendapatkan kompensasi ganti rugi dan atau penggantian apabila barang dan jasa yang diterima tidak sesuai dengan perjanjian atau tidak sebagaimana mestinya;(9). Hak-hak yang diatur dalam ketentuan perundang-undangan (Wangsi dan Rawi, 2018: 1-9).

Sementara pada pasal 5 Undang-Undang Konsumen mengatur mengenai kewajiban konsumen, yakni, pertama, membaca atau mengikuti petunjuk informasi dan prosedur pemakaian aatau pemanfaatan barang atau jasa demi keamanan dan keselamatan.Kedua, beritikad baik dalam melakukan transaksi pembelian barang atau jasa.Ketiga, membayar sesuai dengan nilai tukar yang disepakati.Keempat, mengikuti upaya penyelesaian hukum sengketa perlindungan konsumen secara patut.

Berdasarkan hak dan kewajiban konsumen, maka penyampaian informasi berkaitan dengan produk makanan harus memberikan jaminan bahwa produk makanan tersebut adalah penting terutama bagi umat Islam, dimana halal dan haram adalah ketentuan syariah. Kedua, Undang-Undang Nomor 36 Tahun 2009 tentang Kesehatan.

Undang-undang ini tidak secara eksplisit mengatur tentang produk halal, akan tetapi memberikan peraturan secara umum dalam memproduksi, mengolah, serta mendistribusikan 
makanan dan minuman hasil pengolahan teknologi rekayasa genetik yang aman bagi manusia, hewan, dan lingkungan. Makanan dan minuman yang diedarkan harus memenuhi standar kesehatan dan memperoleh isin edar sesuai dengan peraturan perundang-undangan.

\section{Ketiga, Undang-Undang No 18 tabun 2012 tentang Pangan}

Undang-undang ini adalah undang-undang pengganti UU Nomor 7 Tahun 1996 Tentang Pangan. Dalam konsiderannya menyebutkan bahwa pangan merupakan kebutuhan mendasar manusia yang paling utama pemenuhannya dan merupakan hak azasi manusiayang dijamin oleh Undang-Undang Dasar 1945. oleh karena itu, negara berkewajiban menyediakan, mewujudkan, keterjangkauan dan pemenuhan konsumsi pangan yang aman, bermutu, dan bergizi seimbang. Secara implisit bahkan dinyatakan bahwa pemerintah pusat dan daerah bertanggung jawab menyediakan pangan yang tidak bertentangan dengan agama dan keyakinan, dan budaya masyarakat (Rafani, 2014: 1-6).

Terkait dengan pelabelan halal, pelaku usaha wajib mencantumkan label halal di dalam atau pada kemasan pangan. Kewajiban ini ditujukan untuk produsen domestik maupun produsen impor yang memasuki pasar Indonesia. Pencantuman label halal juga harus dalam bahasa Indonesia yang tegas dan jelas sehingga dapat dimengerti oleh masyarakat. Adapun mengenai iklan dan promosi label halal, maka produsen hrus mempertanggungjawabkan kebenarannya.

\section{Keempat, Peraturan Pemerintab Nomor 69 Tabun 1999 Tentang Label dan Iklan Pangan}

Peraturan Pemerintah ini mengatur tentang label pangan dan iklan pada pasal 2 ayat 1 yang bunyinya: setiap orang yang memproduksi atau memasukkan ke dalam wilayah Indonesia pangan yang dikemas untuk diperdagangkan wajib mencantumkan label pada, di dalam, dan atau di kemasan pangan.Pengaturan tentang keterangan halal pada label diatur dalam pasal tersendiri yakni pada pasal 10 dan pasal 11. Pada pasal 10 ayat 1 menyatakan bahwa: setiap orang yang memproduksi atau memasukkan pangan yang dikemas ke dalam wilayah Indonesia untuk diperdagangkan dan menyatakan bahwa pangan tersebut halal bagi umat Islam, bertanggungjawab atas kebenaran pernyataan tersebut dan wajib mencantumkan tulisan halal pada label. Pencantuman tulisan halal pada label pangan merupakan kewajiban apabila pihak yang memproduksi mengklaim bahwa produknya halal bagi umat Islam. 
ljtihad: Jurnal Wacana Hukum Islam dan Kemanusiaan, Volume 18, No. 2, Desember 2018: 211-226

Kebenaran suatu pernyataan halal pada label pangan tidak hanya dibuktikan dari segi bahan baku, bahan tambahan pangan, atau bahan bantu yang digunakan dalam memproduksi pangan, tetapi harus pula dapat dibuktikan dalam proses produksinya. Oleh karena itu, setiap orang yang memproduksi atau memasukkan kemasan pangan ke dalam wilayah Indonesia untuk diperdagangkan wajib memeriksakan terlebih dahulu pangan tersebut pada lembaga yang berwenang sesuai dengan ketentuan peraturan perundang-undangan (Charity: 101, 2018).

Kelima, Instruksi Presiden Tahun 1991 tentang Peningkatan Pembinaan dan Pengawasan Produksi dan Peredaran Makanan Olahan.

Instruksi Presiden Nomor 2 Tahun 1991 diterbitkan pada tanggal 12 Juni 1991. presiden menginstruksikan kepada Menteri Koordinator Bidang Kesejahteraan Rakyat, Menteri Dalam Negeri, Menteri Kesehatan, Menteri Perindustrian, Menteri Pertanian, Menteri Perdagangan, Menteri Agama, dan para gubernur atau kepala daerah Tingkat I untuk meningkatkan pembinaan dan pengawasan produksi dan peredaran makanan olahan. Dalam instruksi ini presiden menyatakan bahwa masyarakat perlu dilindungi dari produk makanan yang tidak memenuhi syarat dari segi mutu, kesehatan, keselamatan, dan keyakinan agama.

Keenam, Keputusan Menteri dan Keputusan Bersama Menteri.

Terdapat sekurangnya tiga keputusan menteri bersama yang mengatur tentang pencantuman label halal pada kemasan produk makanan yakni:pertama, Keputusan bersama Menteri Kesehatan dan Menteri Agama RI Nomor: 427/Menkes/SKB/VIII/1985, Nomor 68 Tahun 1985 Tentang Pencantuman Tulisan Halal Pada Label Makanan.Kedua, Keputusan Menteri Kesehatan Republik Indonesia Nomor 82 / Menkes/ SK/I/1996 tentang pencantuman tulisan halal pada label makanan yang diubah dengan Keputusan Menteri Kesehatan RI Nomor 924/MENKES/SK/VIII/1996 Tentang Perubahan Atas Kepmenkes RI Nomor 82/Menkes/SK/1996. Ketiga, Surat Keputusan Bersama (SKB) Menteri Agama dan Menteri Kesehatan Nomor 472/MENKES/SKB/VIII/1985 dan Nomor 68/1985 Tentang Pengaturan tulisan halal pada label makanan (Charity, 2018:101) .

Berdasarkan SKB Menteri Agama dan Menteri Kesehatan di atas, maka dibentuklah LPPOM MUI yang didirikan oleh Majelis Ulama Indonesia pada tahun 1989 sebagai lembaga menerbitkan sertifikasi halal sebelum terbentuknya BPJPH. 
Selain peraturan perundangan yang sudah disebutkan di atas, setidaknya terdapat 17 produk peraturan perundangan sebagai basis untuk melindungi konsumen muslim dari bahan makanan yang tidak halal. Dengan demikian, dapat disimpulkan bahwa secara yuridis, pemerintah telah mengatur isu produk pangan halal dan berusaha melindungi konsumen muslim. Namun demikian implementasi peraturan ini di tengah masyarakat tidak dapat diterapkan dengan mudah.

\section{Hambatan terhadap implementasi jaminan produk halal di Kuala Tungkal}

Berdasarkan survey di lapangan, penulis menemukan berbagai macam produk makanan yang tidak memiliki label halal beredar tidak hanya di Kota Kuala Tungkal tetapi juga di Kota Jambi. Produk terbanyak berupa makanan ringan import asal negeri jiran Malaysia dan beberapa asal Korea seperti mie instan, coklat, biskuit, manisan buah, dan kerupuk. Selain produk tersebut, ditemukan juga produk makanan olahan rumah tangga asal produsen lokal, yang tidak memiliki nomor register BPOM dan label halal pada kemasan.Berdasarkan temuan ini, maka penulis melakukan wawancara kepada lembaga terkait yakni ketua MUI Kota Kuala Tungkal H. Abdul Halim Kasim, SH pada 25 Agustus 2018. Penulis melakukan wawancara kepada ketua MUI karena lembaga ini adalah mitra yang ditunjuk oleh pemerintah untuk standarisasi halal, penyelenggaraan sistem jaminan halal, penetapan fatwa, akreditasi lembaga pemeriksa halal, dan sertifikasi auditor halal. Dengan kata lain, MUI adalah salah satu lembaga yang bekerjasama dengan badan lembaga nasional penjamin produk halal (BNP2H) sebagaimana diamanahkan pasal 10 ayat 1 UU no 33 Tahun 2014 (Jahar, 2017: 397).

Berdasarkan wawancara dengan narasumber dapat disimpulkan bahwa peran MUI dalam mengawasi produk makanan halal tidak dapat dikategorikan maksimal. Ketua MUI mengatakan bahwa MUI di Kabupaten Tanjung Jabung Barat selama ini tidak memiliki program kerja khusus terkait makanan halal. Mereka memproses jika ada temuan dan pengaduan dari masyarakat saja. Hal ini terkait dengan terbatasnya anggaran dana yang dimiliki. Pengganggaran kegiatan MUI berasal dari pemerintah daerah, akan tetapi dana yang dikucurkan tidak maksimal, sehingga ketua MUI seringkali menggunakan dana pribadi untuk menutupi kekurangan biaya kegiatan. Apabila terdapat anggaran, pencairannya pun memakan waktu yang lama. Dengan demikian aspek finansial ini secara tidak langsung menjadi hambatan dalam mengawasi produk pangan halal di daerah. MUI Kota Kuala Tungkal bersifat pasif 
ljtihad: Jurnal Wacana Hukum Islam dan Kemanusiaan, Volume 18, No. 2, Desember 2018: 211-226

dan menunggu saja laporan dari masyarakat.

Lebih jauh, ketua MUI justru mengkritik pemerintah Tanjung Jabung Barat yang lebih mengutamakan lembaga adat daripada lembaga Majelis Ulama Indonesia. Menurutnya, terdapat perlakuan istimewa terhadap lembaga adat yang menurutnya hanya memiliki sedikit kontribusi pada masyarakat. Kinerjanya yang sedikit ini ternyata ditopang oleh fasilitas yang cukup signifikan yakni bantuan dana dan gedung perkantoran yang megah. Sementara Majelis Ulama Indonesia yang berperan sebagai lembaga untuk mengurusi umat Islam, tidak memiliki kantor tetap dan dana yang memadai. Kantor MUI berada di rumah pribadi ketua MUI Kabupaten Tanjung Jabung Barat. Sehingga urusan terkait dengan MUI berpindahpindah sesuai dengan domisili sang ketua.

Selain terkait dengan dana, hambatan bagi pengawasan produk pangan halal adalah sumber daya manusia. Hal ini dapat dilihat dari struktur organisasi dan program kerja MUI Kabupaten Tanjung Jabung Barat yang tidak dilakukan secara sistematis dan terprogram. Semua kegiatan berjalan berdasarkan instruksi ketua umum MUI saja. Secara organisatoris, program kerja tidak dapat dilakukan jika tidak ada dukungan dari semua komponen.

Hambatan ketiga yang disampaikan oleh ketua MUI adalah terkait dengan kewenangan MUI di daerah. Fatwa kehalalan produk pangan dikeluarkan oleh MUI pusat. MUI di daerah tidak memiliki kewenangan untuk menetapkan suatu produk pangan halal atau haram. MUI melalui LPPOM dan komisi fatwa berupaya untuk memberikan jaminan produk halal melalui instrumen labelisasi halal. Kendala SDM terkait dengan jumlah audit eksternal dan masa tunggu pelaporan halal kepada MUI setiap 6 bulan secara berkala. Waktu tunggu yang lama ini dikhawatirkan terjadi kecurangan oleh para pengusaha dengan mencampur produk dengan bahan non halal (Prabowo: 2018). oleh karena itu perlu kesadaran pelaku usaha agar tetap konsisten menjaga produknya halal walaupun tanpa pengawasan dari MUI. Faktor penghambat lainnya adalah, ketidakjujuran pelaku usaha untuk memperpanjang sertifikasi halal pada labelnya ketika sudah habis masa berlakunya.

Untuk memperkuat argumen penulis tentang riset ini, penulis juga menggali data dari kantor BPPOM Propinsi Jambi selaku badan pengawas obat dan makanan. Kasi Sertifikasi dan Pelayanan Informasi BPOM Propinsi Jambi (Sartani), memberikan keterangan terkait dengan peredaran pangan. Menurutnya, BPOM tidak memiliki kewenangan untuk mengawasi 
kehalalan produk pangan halal. Terkait dengan program kerja, BPOM memiliki fungsi sebagaimana diatur oleh Kepres nomor 103 tahun 2001 yaitu: pengkajian dan penyusunan kebijakan nasional di bidang pengawasan obat dan makanan, pelaksanaan kebijakan tertentu bidang pengawasan obat dan makanan (Taufikurrahman, 2016:57). Dalam pengawasan obat dan makanan, BPPOM hanya mengkaji kandungan makanan, apakah mengandung bahan yang berbahaya atau tidak seperti formalin, rhodamin B, dan boraks, bukan terkait dengan kehalalan produk pangan.

BPPOM juga cenderung pasif terhadap pengawasana makanan. Biasanya BPOM menunggu laporan dari masyarakat. Apabila ditemukan makanan yang membahayakan, BPPOM baru turun ke lapangan untuk mengambil sampel. Apabila hasil sampel positif memiliki kandungan bahan pangan yang berbahaya, maka produsen akan diberikan sanksi. Meskipun begitu, sanksi yang diberikan tidak selalu sanksi pidana. BPPOM menggunakan nurani untuk menghakimi seseorang, karena pada umumnya produsen yang tertangkap berasal dari industri rumah tangga sederhana.

Program kerja rutin BPPOM yang nampak terlihat adalah sidak pada pasar swalayan dan supermarket menjelang lebaran di setiap tahun. Program ini memang bertujuan untuk mencari makanan atau bahan pangan yang sudah kadaluarsa atau mengandung bahan-bahan berbahaya seperti pewarna kimia dan pengawet mayat. Kegiatan rutin tahunan ini melibatkan beberapa instansi dan lembaga sebagai mitra kerja di lapangan, seperti Kepolisian, Kejaksaan, Dinas Perindustrian, Perdagangan dan Koperasi, Kementerian Agama serta lembaga non pemerintahan seperti LSM, Media cetak/online dan YLKI. Beberapa temuan yang pernah dicatat oleh BPPOM adalah menyangkut kemananan produk makanan, minuman dan obatobatan yang beredar di masyarakat.

Perlu difahami bahwa kegiatan rutin seperti di atas hanya dilaksanakan dengan volume tertentu untuk seluruh wilayah propinsi Jambi. Artinya, tidak bisa dilakukan secara rutin dan terjadwal, melainkan disesuaikan dengan ketersediaan anggaran yang ada. Propinsi Jambi hanya memiliki satu kantor yang terletak di Kota Jambi dan satu lainya terletak di Kota Sungai Penuh Propinsi Jambi. Praktis hanya itu kondisi BPPOM yang ada utuk kemudian diharapkan dapat menjangkau semua wilayah di dalam Propinsi Jambi yang memiliki wilayah dari Ujung Jabung sampai Teluk Duri seluas $50.0582 \mathrm{~km}$. 
ljtihad: Jurnal Wacana Hukum Islam dan Kemanusiaan, Volume 18, No. 2, Desember 2018: 211-226

\section{Penutup}

Jaminan produk pangan halal terutama di Kuala Tungkal dan Kota Jambi belum terlihat implementasinya di lapangan. Masih ditemukannya produk pangan yang tidak memiliki label halal pada kemasannya. Hal ini mengindikasikan gagalnya pemerintah dalam menjamin konsumen muslim terbebas dari barang-barang haram. Memang sudah ada upaya melindungi konsumen muslim dari pengaruh zat-zat haram pada produk pangan melalui berbagai peraturan perundang-undangan, akan tetapi masih banyak terdapat kendala dan hambatan.

Hambatan utama jaminan produk halal di Kuala Tungkal dan Kota Jambi terkait dengan keterbatasan kewenangan MUI di daerah untuk mengeluarkan fatwa halal, keterbatasan anggaran dana pemerintah daerah, kapabilitas sumber daya manusia dan kurangnya infrastruktur untuk mengawasi peredaran produk pangan halal. Sementara BPOM hanya mengawasi keamanan kandungan makanan dan obat-obatan saja. Dengan demikian perlu kesadaran masing-masing individu dan pelaku usaha untuk mengkonsumsi dan memproduksi pangan halal dan thayyib sebagaimana temuan medis bahwa makanan tersebut menjaga eksistensi umat manusia.

\section{Daftar pustaka}

Al-Ghazali, Imam.Rahasia Halal dan Haram: Hakikat Batin Perintah dan Larangan Allah. Terjemahan Iwan Kurniawan. Bandung: Mizan, 2007.

Asy'ari, Hasyim. Kriteria Makanan Halal dalam Perspektif Ibnu Hazm dan MUI. Repository uinjkt.ac.id

Baharuddin, Moh. “Problem Sertifikasi Halal Produk Pangan Hewani”, Jurnal AsasVol. 2 No. 6(2010): p.1-10.

Chairunnisyah, S. "Peran Majelis Ulama Indonesia Dalam Menerbitkan Sertifikat Halal Pada Produk Makanan Dan Kosmetika”, EduTecb: Jurnal Ilmu Pendidikan dan Ilmu Kesehatan Vol.3 No 2 (2017): p. 64-74.

Charity, May Lim."Jaminan Produk Halal Di Indonesia (Halal Products Guarantee In Indonesia)”, Jurnal Legislasi IndonesiaVol. 14 No. 1 (2018): p.99-107.

Endah, Hadiati Nur. "Perilaku Pembelian Kosmetik Berlabel Halal Oleh Konsumen indonesia", Jurnal Ekonomi dan Pembangunan Vol. 22 No. 1 (2017): p. 25-39

Engel, Rafael J. and Schutt, Russell K. Fundamentals of Social Work Reserchs. California: Sage Publishing, 2010 
Faidah, Mutimmatul."Sertifikasi Halal di Indonesia dari Civil Society menuju Relasi Kuasa antara Negara dan Agama", ISLAMICA: Jurnal Studi KeislamanVol. 11 No. 2(2017): p. 449-476.

Fauzi, M. "Problematika Penentuan Fatwa Hukum Halal di Indonesia”, Jurnal Ilmiah Ekonomi Islam Vol 4, No. 1 (2017): p. 51-62.

Hosanna, Melissa Aulia\&Nugroho, Susanti Adi. "Pelaksanaan undang-Undang Nomor 33 Tahun 2014 Tentang Jaminan Produk Halal Terhadap Pendaftaran Sertifikat Halal Pada Produk Makanan”, Jurnal Hukum Adigama Vol.1 No.1 (2018): p.1-24.

Hutchinson, Francis E. and Chong, Terence . The SIJORI Cross Border Region: Trans National Politics, Economics, and Culture. Singapore, ISEAS, 2016.

Ilyas. Musyfikah. "Sertifikasi Labelisasi Produk Halal Perspektif Maslahat". Jurnal al-Qadau: Peradilan dan Hukum Keluarga Islam Vol. 4 No. 2 (2018): p. 357-376.

Jahar, Asep Saepudin dan Thalhah. "Dinamika Sosial Politik Pembentukan Undang-Undang Jaminan Produk Halal”. al-Abkam Vol.12, No. 2 (2017): p. 385-404.

Man, S. dan Yahya, Zainal Abidin. Halalkah Makanan Kita? Selangor: PTS Islamika, 2014.

Muhammad, Zawanah, Munir Md Salleh, Abdul Muhaimin Mahmood. Halal Antara Tuntutan Agama dan Strategi Ekonomi. Seminar Pentadbiran Hal Ehwal Islam di Malaysia: Cabaran Semasa dan Perancangan Masa Depan. 2008.

Nugraha, R., MK Mawardi. “Labelisasi Halal Terhadap Minat Beli Konsumen (Survei Pada Mahasiswa Muslim Konsumen Mie Samyang Berlogo Halal Korean Muslim Federation Di kota Malang".Jurnal Administrasi Bisnis Vol 50 No.5 (2017): p.113-120.

Prabowo, Ricky. Tinjauan Hukum Islam Terhadap Prosedur Pengajuan Sertifikasi Halal Pada Produk Makanan Olahan Keripik Pisang (Studi Pada Lembaga Pengkajian Obat-Obatan dan Kosmetika. Thesis undergraduate radenintan.ac.id

Prabowo, S. dan AA Rahman. "Sertifikasi Halal Industri Pengolahan Hasil Pertanian". Forum Penelitian Agro Ekonomi Vol.34 No 1(2016): p.57-70

Praja, CBE\&Kurniaty, Yuni. "Kendala dan Upaya Pemerintah dalam Penerapan UndangUndang Nomor 33 tahun 2014 tentang Jaminan Produk Halal di Kota Magelang". Proceeding The $6^{\text {th }}$ University ResearchColloquiumURECOL(2017)

Sasmito, Adi. Analisis Kebijakan MUI dan BPOM dalam Labeling Obat dan Makanan. UI: Fakultas Kesehatan Masyarakat.2008.

ShidiqGhafar. Teori Maqasid Syariah Dalam Hukum Islam. Majalab Ilmiah Sultan Agung Vol. 44, No 118(2019):p.117-130.

Suparti, E.,_Giyanti. "Model Konseptual Penerimaan Teknologi Halal MUI Berbasis Technology Acceptance Model”.Proceeding IENACO (2017) - publikasiilmiah.ums.ac.id 
ljtihad: Jurnal Wacana Hukum Islam dan Kemanusiaan, Volume 18, No. 2, Desember 2018: 211-226

Teddie, Charles and Tashakkori.Abbas.Foundations of Mixed Methods Research. California: Sage Publishing, 2009.

Triyanto, WA. "Sertifikasi Jaminan Produk Halal Menurut Undang-Undang Nomor 33 Tahun 2014 (Perspektif Hukum Perlindungan Konsumen)”. Lex Administratum, (2017): p.1

Wahyuningrum, A\&Anasom. “Strategi Dakwah MUI (Majelis Ulama Indonesia) Jawa Tengah Melalui Sertifikasi Halal”.Jurnal Ilmu DakwabVol. 35 No. 2 (2015): p.186-206.

Wangsi, Muthia Mitta\&Rawi, Rais Dera Pua. "Perlindungan Konsumen Dalm Pelabelan Produk Menurut Ekonomi Islam". sentralisasi Vol. 7 No 1 (2018): pp. 1-9

Zulham, S. Peran Negara dalam Perlindungan Konsumen Muslim Terhadap Produk Halal. Jakarta: Kencana, 2018.

\section{Sumber Internet}

www.jdih.po.go.id

www.kajanglakonews.com

www.lintastungkal.com

www.peraturan.go.id

www.setkab.go.id

www.simbi.kemenag.co.id 